\title{
Antioxidant enzymes activities in Vicia seedlings during drought stress
}

\author{
Dušica Jovičić · Zorica Nikolić · Aleksandar Mikić · Branko Milošević · \\ Dragana Milošević · Maja Ignjatov · Dragana Marinković
}

Institute of Field and Vegetable Crops, Maksima Gorkog 30, 21000 Novi Sad, Serbia

\begin{abstract}
Summary: Drought greatly affects normal plant growth, endangering physiological and biochemical processes in plants. Under the influence of unfavorable environmental conditions, antioxidant protection systems in plant cell can be activated regardless of the stage of growth and development of plants. The experiment was conducted on three vetches species ( $V$. sativa, $V$. villosa and $V$. pannonica) under PEG-induced drought stress. Activity of antioxidant enzymes: superoxide dismutase (SOD, EC 1.15.1.1), ascorbate peroxidase (APx, EC 1.11.1.1) and catalase (CAT, EC 1. 11. 1. 6), was determined in shoots and roots of 10-day-old seedlings. Lack of water during germination period activated all the examined antioxidant enzymes in both organs of all tested Vicia species. The activity of SOD and APx generally increased at higher stress levels, while the enzyme CAT showed different patterns of action in all tested species. The results of this study suggest that drought stress causes the production of oxygen radicals that lead to oxidative stress in plants.

Key words: antioxidative enzymes, drought, oxidative stress, Vicia
\end{abstract}

\section{Introduction}

When it comes to agricultural production, one of the biggest problems is water deficiency, which causes reduced average yield of most major crops worldwide (Zlatev \& Lidon, 2012). Drought greatly affects normal plant growth and morphological structure, endangering physiological and biochemical processes in plants (Jill et al., 2012, Zarafshar et al., 2014). It occurs as a result of reduced amount of water in the soil, but it can also occur as a result of disruption in water adoption by plants. The problem is also worsened by the fact that drought can occur as a result of increased salt content in the soil or reduced air humidity, which is often accompanied by high air temperature. Therefore, this category of the abiotic factor is often characterized as a multidimensional stress.

In conditions of insufficient water, in plant cell there are over-generations of reactive oxygen species (ROS) that are responsible for the oxidation of cellular components like proteins, lipids, DNA and RNA, and as a final consequence can cause cell death (De Carvalho, 2008). Water stress affects wide range plant responses, from cell-level changes to reducing growth

Corresponding author:

dusica.jovicic@ifvens.ns.ac.rs

Acknowledgements:

This study was funded by the Serbian Ministry of Education, Science and Technological Development within the project TR 31024. rates. In order to neutralize ROS, plants developed defense mechanisms known as antioxidant systems that regulate the amount of these oxygen species depending on the needs of the cell (Hossain et al., 2012). Under the influence of unfavorable environmental conditions, antioxidant protection systems can be activated regardless of the stage of growth and development of plants. Gutterman (2002) believes that the seed is most resistant to adverse environmental conditions, but seedlings are the most vulnerable. In addition, the process of seed germination is not possible without water and because of this drought significantly affects the process of germination, emergence and seedling establishment. The defense of oxidative stress during the germination and initial growth phase is of great importance because it is precisely oxidative stress that directly affects the decrease in cells division, and thus limits and blocks the growth and development of plants (Azadi et al., 2013).

Species of the genus Vicia are some of the highquality and cost-effective forms of bulky fodder in many regions with moderate climatic conditions. Due to its high nutritional value, vetches are some of the most cultivated forage legumes, suitable for the production of animal feed. In addition, they are nitrogen-fixing leguminous plants useful as natural soil fertiliser (Abbasi et al., 2014). In Serbia, the economically most significant vetches are $V$. sativa, $V$. villosa and $V$. pannonica (Vujaković et al., 2011). Although they are suitable for growing in a wide range of climatic and soil conditions, Vicia spp. are often susceptible to drought. 
Considering the significance of the antioxidative mechanism for survival and struggle against stress factors, the improvement of the antioxidant potential is an important target for plant breeding (Damerum et al., 2015). The present study was designed to examine antioxidant enzyme responses to drought stress in a three different Vicia spp. in order to assess their breeding potential for the creation of drought tolerant varieties and hybrids.

\section{Material and Methods}

The seeds of three vetches species (Vicia sativa, Vicia villosa, Vicia pannonica) were sown in plastic pots filled with sterile sand and moistened to field capacity. In controlled conditions, moisturising was performed with distilled water, while drought stress was stimulated with PEG (Polyethylene Glycol 6000 - PEG 6000) in two different osmotic potential levels (-0.3 $\mathrm{MPa},-0.6 \mathrm{MPa})$ measured by potentiometer (WP4C, Decagon Devices, Inc, USA). The pots were placed in a germination chamber at $20^{\circ} \mathrm{C}$. After 10 days, the seedlings' shoots and roots were separately collected and used for analysis.

\section{Determination of Antioxidant Enzymes Activity}

One gram of fresh plant material (shoot and root) were ground in the ice bath with $10 \mathrm{ml}$ phosphate buffer ( $\mathrm{pH} 7.8,50 \mathrm{mM}$ ), followed by centrifugation for $10 \mathrm{~min}$.
The supernatant was collected for enzyme assays. The superoxide dismutase (SOD) activity was determined by the Auclair and Voisin method (1985) based on the ability of the superoxide radical to reduce nitro-blue tetrazolium (NBT) in which blue formazane is formed. Reducing yellow coloured NBT to blue formazan is used as a measure of the generation of superoxide radicals in chemical and biological systems. Glass test tubes containing the mixture were illuminated with a fluorescent lamp, while tubes which were not illuminated were used as blanks. After the illumination for $4 \mathrm{~min}$, the absorbance was measured at $560 \mathrm{~nm}$. One unit of SOD activity was defined as the amount of enzyme required to cause $50 \%$ inhibition of the NBT photoreduction rate. Enzyme activity was expressed by the number of $U$ ("unit") per mg of protein. Soluble protein content was determined according to Bradford (1976).

The activity of ascorbate peroxidase (APx) was measured by following the oxidation of ascorbate to dehydroascorbate (Nakano \& Asada, 1981). The plant extract was mixed potassium phosphate buffer $(\mathrm{pH} 7$, $100 \mathrm{mM}), 0.1 \mathrm{mM}$ EDTA, $1 \mathrm{mM} \mathrm{H}_{2} \mathrm{O}_{2}$ and $0.25 \mathrm{mM}$ ascorbate. The enzyme activity was determined by measuring the decrease in absorbance at $290 \mathrm{~nm}$ for 1 min. One unit of APx activity is defined as the amount of enzyme required for the oxidation of $1 \mu \mathrm{mol}$ of ascorbate per minute.

The catalase (CAT) activity was determined by observing the disappearance (degradation) of $\mathrm{H}_{2} \mathrm{O}_{2}$ according to the method of Aebi (1984). One unit of

Table 1. Analysis of variance of main effects and interactions for superoxide dismutase (SOD), ascorbate peroxidase (APx) and catalase (CAT) under PEG-induced stress in the shoot and the root of $V$. sativa, $V$. villosa and $V$. pannonica

\begin{tabular}{|c|c|c|c|c|c|c|}
\hline & \multicolumn{3}{|c|}{ SOD (shoot) } & \multicolumn{3}{|c|}{ SOD (root) } \\
\hline & $\mathrm{SS}(\%)$ & MS & $\mathrm{p}$ & $\mathrm{SS}(\%)$ & MS & $\mathrm{p}$ \\
\hline Treatment $(\mathrm{T})$ & 66.0 & 55.15 & $0.000^{* *}$ & 78.1 & 53.69 & $0.000 * *$ \\
\hline Species (S) & 26.0 & 21.73 & $0.000^{* *}$ & 13.8 & 9.49 & $0.000 * *$ \\
\hline \multirow[t]{3}{*}{$\mathrm{T} \times \mathrm{S}$} & 8.0 & 3.36 & $0.000^{* *}$ & 8.1 & 2.78 & $0.000 * *$ \\
\hline & \multicolumn{3}{|c|}{ APx (shoot) } & \multicolumn{3}{|c|}{$\mathrm{APx}$ (root) } \\
\hline & $\mathrm{SS}(\%)$ & MS & $\mathrm{p}$ & $\mathrm{SS}(\%)$ & MS & $\mathrm{p}$ \\
\hline Treatment $(\mathrm{T})$ & 38.2 & 534.91 & $0.000^{* *}$ & 92.4 & 18279.11 & $0.000 * *$ \\
\hline Species (S) & 55.8 & 781.32 & $0.000^{* *}$ & 3.6 & 715.08 & $0.000 * *$ \\
\hline \multirow[t]{3}{*}{$\mathrm{T} \times \mathrm{S}$} & 6.0 & 42.44 & $0.000^{* *}$ & 4.0 & 391.92 & $0.000 * *$ \\
\hline & \multicolumn{3}{|c|}{ CAT (shoot) } & \multicolumn{3}{|c|}{ CAT (root) } \\
\hline & $\mathrm{SS}(\%)$ & MS & $\mathrm{p}$ & $\mathrm{SS}(\%)$ & MS & $\mathrm{p}$ \\
\hline Treatment $(\mathrm{T})$ & 79.9 & 235.59 & $0.000^{* *}$ & 16.5 & 32.32 & $0.000 * *$ \\
\hline Species (S) & 10.5 & 30.95 & $0.000^{* *}$ & 3.3 & 201.16 & $0.000 * *$ \\
\hline $\mathrm{T} \times \mathrm{S}$ & 9.6 & 14.13 & $0.000^{* *}$ & 80.2 & 255.05 & $0.000^{* *}$ \\
\hline
\end{tabular}

$* * \mathrm{P}<0.01$ 
Table 2. The activities of superoxide dismutase (SOD), ascorbate peroxidase (APx) and catalase (CAT) under PEG-induced stress in the shoot and the root of $V$. sativa, V. villosa and $V$. pannonica

\begin{tabular}{|c|c|c|c|c|c|c|c|}
\hline & & \multicolumn{2}{|c|}{$\mathrm{SOD}(\mathrm{U} / \mathrm{mg}$ of protein) } & \multicolumn{2}{|c|}{$\mathrm{APx}(\mathrm{U} / \mathrm{mg}$ of protein $)$} & \multicolumn{2}{|c|}{$\mathrm{CAT}(\mathrm{U} / \mathrm{mg}$ of protein) } \\
\hline & & shoot & root & shoot & root & shoot & root \\
\hline & $\begin{array}{l}\text { Controlled } \\
\text { conditions }\end{array}$ & $7.05^{\mathrm{g}} \pm 0.17$ & $12.44 \mathrm{~g} \pm 0.27$ & $50.22^{\mathrm{f}} \pm 0.13$ & $67.20^{\mathrm{h}} \pm 2.71$ & $10.43 \mathrm{e} \pm 1.21$ & $18.43 \mathrm{~g} \pm 0.23$ \\
\hline \multirow[t]{3}{*}{ V. sativa } & PEG - $0.3 \mathrm{MPa}$ & $10.64 \mathrm{~d} \pm 0.32$ & $15.55^{\mathrm{d}} \pm 0.32$ & $60.74 c \pm 0.45$ & $133.37 \mathrm{~d} \pm 1.09$ & $10.77 \mathrm{e} \pm 0.40$ & $25.77 c \pm 0.50$ \\
\hline & PEG -0.6 MPa & $12.28 \mathrm{c} \pm 0.32$ & $18.16^{\mathrm{b}} \pm 0.06$ & $55.03 \mathrm{e} \pm 0.85$ & $157.31 \mathrm{~b} \pm 0.38$ & $20.64 \mathrm{~b} \pm 0.97$ & $22.77 \mathrm{e} \pm 0.39$ \\
\hline & $\begin{array}{l}\text { Controlled } \\
\text { conditions }\end{array}$ & $7.14 \mathrm{~g} \pm 0.17$ & $12.94 \stackrel{f}{ \pm} 0.17$ & $48.07 \mathrm{~g} \pm 0.48$ & $74.70 \mathrm{~g} \pm 0.41$ & $13.64 \mathrm{~d} \pm 0.46$ & $32.29^{a} \pm 1.01$ \\
\hline \multirow[t]{3}{*}{ V. villosa } & PEG -0.3 MPa & $9.43 \mathrm{e} \pm 0.30$ & $14.99 \mathrm{e} \pm 0.22$ & $60.23^{\mathrm{cd}} \pm 0.52$ & $129.43 \mathrm{e} \pm 0.68$ & $11.18 \mathrm{e} \pm 0.39$ & $28.92^{\mathrm{b}} \pm 0.42$ \\
\hline & PEG -0.6 MPa & $10.12^{\mathrm{d}} \pm 0.18$ & 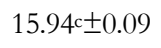 & $61.07 \mathrm{c} \pm 0.43$ & $142.77 \mathrm{c} \pm 1.08$ & $17.39 c \pm 0.35$ & $20.07^{f} \pm 1.00$ \\
\hline & $\begin{array}{l}\text { Controlled } \\
\text { conditions }\end{array}$ & $8.14 \mathrm{f} \pm 0.16$ & $13.17 \mathrm{~d} \pm 0.14$ & $59.11^{\mathrm{d}} \pm 0.94$ & $77.91^{\mathrm{f}} \pm 0.25$ & $12.98^{\mathrm{d}} \pm 0.21$ & $19.29 \mathrm{fg} \pm 0.09$ \\
\hline \multirow[t]{2}{*}{$V$.pannonica } & PEG $-0.3 \mathrm{MPa}$ & $14.17 \mathrm{a} \pm 0.65$ & $18.09 \mathrm{a} \pm 0.16$ & $79.60^{\mathrm{a}} \pm 1.34$ & $134.74 \mathrm{~d} \pm 0.48$ & $13.76^{\mathrm{d}} \pm 0.27$ & $24.01^{\mathrm{d}} \pm 0.30$ \\
\hline & PEG -0.6 MPa & $13.57 \mathrm{~b} \pm 0.48$ & $18.70^{\mathrm{b}} \pm 0.19$ & $77.29 b \pm 0.38$ & $185.07 \mathrm{a} \pm 0.30$ & $24.91 \mathrm{a} \pm 0.37$ & $25.15 \mathrm{c} \pm 0.16$ \\
\hline
\end{tabular}

*each value with the same letter is at the same level of significance for $95 \%$ interval compared by Duncan's multiple comparison test.

CAT activity was defined as the amount of enzyme that catalyzes the decomposition of $1 \mu \mathrm{mol}$ of $\mathrm{H}_{2} \mathrm{O}_{2}$ per minute.

Three replicates were performed for each treatment. The data were analyzed using two-way factorial analysis of variance followed by the post hoc Duncan multiple range test.

\section{Results and Discussion}

The average values of the activity of the investigated antioxidative enzymes in tested shoots and roots are presented in Table 2. ANOVA determined the high contribution of species and treatments as well as their interactions $(p<0.001)$ on the activity of all exanimated antioxidant enzymes in both, shoots and roots (Table 1).

SOD activity increased with heightening drought intensity in both shoot and root of $V$. sativa and $V$. villosa (Table 2). At the highest level of stress $(-0.3 \mathrm{MPa})$, the activity of this enzyme was observed in $V$. pannonica, indicating that this enzyme could not overcome the amount of ROS occurring in the shoot at this level of stress. The SOD activity in the root increased with increasing drought intensity in all investigated species. The highest values in the root were observed in $V$. pannonica both in controlled conditions and in exposure during stress exposure.Many studies have shown that SOD is one of the first activated enzymes in stressful environments, whereby it participates in the reaction of dismutations of superoxide radicals, transforming them into less toxic $\mathrm{O}_{2}$ and $\mathrm{H}_{2} \mathrm{O}_{2}$. Thus, SOD reduces the risk of the formation of a more reactive hydroxyl radical (Meloni et al., 2003, Gill and Tuteja, 2010). Chakhchar et al. (2016) state that this enzyme has a crucial role in the survival of plants in stressful conditions. The significance of this enzyme is also shown by the fact that an excessive expression of SOD in transgenic tobacco plants showed tolerance to multiple stresses, such as drought and salinity (Badawi et al., 2004). The increased activity of this enzyme in the shoot and the root in all examined vetches with increasing stress intensity confirmed these allegations, indicating its importance in neutralizing ROS and reducing oxidative stress in conditions of insufficient water quantity. Further, the decrease in SOD activity, as observed in the root of $V$. pannonica at 0.6 , may indicate that the scavenger activity of this enzyme is threatened or may be the result of an adaptation of plants to salt stress (Shahbazi et al., 2011).

In the shoots of $V$. sativa and $V$. villosa, the $\mathrm{APx}$ activity increased during moderate stress (-0.3 $\mathrm{MPa})$ and then decreased with further increase in drought intensity (-0.6 MPa) (Table 2). In the root of all studied species, the activity of this enzyme increased with increasing drought intensity. Such results indicate that at the root of all the studied vetches, the ROS removal mechanism is based on a constantly increased activity of SOD and APx. Since APx is a component of the ascorbate-glutathione pathway and plays an important role in the process of $\mathrm{H}_{2} \mathrm{O}_{2}$ scavenging, this enzyme is a significant factor in the removal of excess cellular ROS (Foyer \& Noctor, 2005). In this experiment, APx was unable to neutralize a large amount of ROS generated at the highest level of stress. Increased expression of APx affects the increased activity of this antioxidant enzyme and thus protects the shoots and roots from oxidative stress (De Souza et al., 2013). Studying rice plants, Demiral and Turkan (2005) observed a positive correlation between increased APx activity and lower intensity of lipid peroxidation, the main cause of cell membrane damage. Increased peroxidase activity under 
the influence of osmotic stress caused by the solution of PEG 6000 was found in tolerant genotypes of clover (Wang et al., 2011), oilseed rape (Mirzaee et al., 2013) and sugar beet (Sen\&Alikamanoglu, 2013).

In the shoot of $V$. sativa and $V$. pannonica, CAT activity increased in $-0.3 \mathrm{MPa}$ stress level, but the difference compared to controlled conditions was not statistically significant (Table 2). The highest CAT activity in the shoot was observed at the highest drought intensity in all examined vetches. This enzyme in the root of all tested species showed different patterns of action. In $V$. sativa, CAT activity was increased at low stress level but decrease at high stress level. In V. villosa, activity was the highest in controlled conditions, but decreased following drought stress. In V. pannonica activity of this enzyme was increasedwith increasing stress intensity. Increased CAT activity in wheat under drought stress was recorded especially in sensitive varieties (Simova-Stoilova et al., 2010). In contrast, Sharma and Dubey (2005) observed a decrease in CAT activity in rice seedlings during drought stress.

\section{Conclusions}

All three Vicia species showed significant antioxidant activity in stressful drought conditions compared with control, but it was not possible to distinguish species with the most intensive antioxidative responses based on these results. Therefore, more detailed research is needed to find the parameters of the oxidative status that would more reliably rank species according to their drought tolerance.

The results of this study suggest that drought stress causes the production of oxygen radicals that lead to oxidative stress in plants. PEG-induced drought activated antioxidant enzymes SOD, APx and CAT in shoot and root of all tested Vicia species. Therefore, it is very important that newly developed varieties and hybrids have well developed anti-oxidant protection systems since this is the key to adjusting and overcoming permanent climate change.

\section{References}

Abbasi, A.R, Sarvestani, R., Mohammadi, B., Baghery, A. (2014). Drought Stress-Induced Changes at Physiological and Biochemical Levels in Some Common Vetch (Vicia sativa L.) Genotypes. Journal of Agricultural Science and Technology, 16: 505-516.

Aebi, H, (1984), Catalase in Vitro.Method in Ensymology, 105, 121-126.

Auclair, C., Voisin, E. (1985). Nitroblue Tetrazolium Reduction. In: Greenwald, R.A. (Ed.) Handbook of Methods for Oxygen Radical Research (pp.123-132). CRC Press, Boca Raton.

Azadi, M.S., Younesi, E., Tabatabaei, S.A. (2013). Seed Germination, Seedling Growth and Enzyme Activity of Wheat Seed Primed under Drought and Different Temperature Conditions. Journal of Stress Physiology \& Biochemistry, 9(4), 310-318.

Badawi, G.H., Yamauchi, Y., Shimada, E., Sasaki, R., Kawano, N., Tanaka, K., Tanaka, K. (2004). Enhanced Tolerance to Salt Stress and Water Deficit by Overexpressing Superoxide Dismutase in
Tobacco (Nicotiana tabacum) Chloroplasts. Plant Science, 166, 919-928. doi: 10.1016/j.plantsci.2003.12.007

Bradford M.M. (1976). Rapid and sensitive method for quantitation of microgram quantities of protein utilising principle of protein dye binding. Analytical Biochemistry, 72, 248-254.

Chakhchar, A., Lamaoui, M., Aissam, S., Ferradous, A., Wahbi, S., El Mousadik, A. Ibnsouda-Koraichi S., Maltouf, A.F., El Modafar, C. (2016). Differential Physiological and Antioxidative Responses to Drought Stress and Recovery Among Four Contrasting ArganiaSpinosa Ecotypes. Journal of Plant Interactions, 11(1), 30-40. doi: 10.1080/17429145.2016.1148204

Damerum A., Selmes S., Biggi G., Clarkson G., Rothwell S., Truco M.J., Michelmore R., Hancock R., Shellcock C., Chapman M., Taylor G. (2015). Elucidating the genetic basis of antioxidant status in lettuce (Lactuca sativa). Horticulture Research 2, 15055. doi:10.1038/ hortres.2015.55

De Carvalho, M.H.C. (2008).Drought Stress and Reactive Oxygen Species: Production, Scavenging and Signaling.Plant Signaling \& Behavior, 3, 156-165.

De Souza, M.O., Pelacani, C.R., Willems, A.J.L., De Castro, D.R., Hilhorst, W.M.H., Ligterink, W. (2016): Effect of Osmopriming on Germination and Initial Growth of Physalisangulata L. Under Salt Stress and on Expression of Associated Genes. Annals of the Brazilian Academy of Sciences 88(1),503-516. doi: 10.1590/00013765201620150043

Demiral, T., Turkan, I. (2005). Comparative Lipid Peroxidation, Antioxidant Systems And Proline Content in Roots of Two Rice Cultivars Differing in Salt Tolerance. Environmental and Experimental Botany, 53, 247-257. doi: 10.1016/j.envexpbot.2004.03.017

Foyer, C.H., Noctor, G. (2005). Oxidant and Antioxidant Signalling in Plants: A Re-EvaluAtion of the Concept of Oxidative Stress In A Physiological Context.Plant Cell \& Environmental, 28, 1056-1071. doi: 10.1111/j.1365-3040.2005.01327.x

Gill, S.S., Tuteja, N. (2010).Reactive Oxygen Species and Antioxidant Machinery in Abiotic Stress Tolerance in Crop Plants.Plant Physiology and Biochemistry, 48, 909-930.doi: 10.1016/j.plaphy.2010.08.016

Gutterman, Y. (2002). Survival strategies of annual desert plants. Berlin: Springer-Verlag.

Hossain, M.A., Piyatida, P., Teixeira da Silva, J.A., Fujita, M. (2012). Molecular Mechanism of Heavy Metal Toxicity and Tolerance in Plants: Central Role Of Glutathione in Detoxification of Reactive Oxygen Species and Methylglyoxal and in Heavy Metal Chelation. Journal of Botany, 1-37. doi:10.1155/2012/872875

Jill, E.C., Ciro, S., Mateo, V. (2012). Dissecting Maize Productivity, Ideotypes Associated With Grain Yield under Drought Stress and Well Watered Conditions. Journal of Integrative Plant Biology,54(12), 1007-1020.

Meloni, D.A., Oliva, M.A., Martinez, C.A., Cambraia, J. (2003).Photosynthesis and activity of superoxide dismutase, peroxidase and glutathionereductase in cotton under salt stress.Environmental and Experimental Botany, 49: 69-76.doi: 10.1016/S0098-8472(02)00058-8

Mirzaee, M., Moieni, A., Ghanati, F. (2013).Effects of Drought Stress on the Lipid Peroxidation and Antioxidant Enzyme Activities in Two Canola (Brassica napus L.)Cultivars.Journal of Agricultural Science and Technology, 15, 593-602.

Nakano, Y., Asada.K. (1981). Hydrogen Peroxide is Scavengedby Ascorbate Specific Peroxidase in Spinach Chloroplasts. Plant and Cell Physiology, 22, 867-880.

Sen, A., Alikamanoglu, S. (2013). Antioxidant Enzyme Activities, Malondialdehyde, And Total Phenolic Content of PEG-Induced Hyperhydric Leaves In Sugar Beet Tissue Culture. In Vitro Cellular \& Developmental Biology - Plant 49(4), 396-404. doi: 10.1007/ s11627-013-9511-2

Shahbazi, E., Arzani, A.,Saeidi, G.(2011). Effects of NaCl Treatments on Seed Germination and Antioxidant Activity of Canola (Brassica napus L.) Cultivars. Bangladesh Journal of Botany 41(1), 67-73.

Sharma, P. and Dubey, R.S. (2005).Lead Toxicity in Plants. Brazilian Journal of Plant Physiology, 17, 1-19. doi:10.1590/s167704202005000100004 
Simova-Stoilova, L., Vaseva, I., Grigorova, B., Demirevska, K., Feller, U. (2010).Proteolytic Activity and Cysteine Protease Expression in Wheat Leaves under Severe Soil Drought and Recovery.Plant Physiology and Biochemistry, 48, 200-206. doi:10.1016/ j.plaphy.2009.11.003

Vujaković, M.Jovičić, D., Karagić, Đ., Mikić, A., Nikolić, Z.,Petrović, D.,Taški -Ajduković, K. (2011).Pokazatelji životne sposobnosti semena ozimih grahorica (Vicia spp.). Ratarsto I pourtarstwo, 48, 131-136

Wang, C.Q., Liu, T., Xu, H.J. (2011). Ascorbate-Glutathione Metabolism during PEG Induced Water Deficit in Trifoliumrepens. Russian Journal of Plant Physiology, 58, 597-602. doi:10.1134/ S1021443711040248
Zarafshar, M., Akbarinia, M., Askari, H., Mohsen Hosseini, S., Rahaie, M., Struve, D., Striker, G., G. (2014). Morphological, Physiological and Biochemical Responses to Soil Water Deficit in Seedlings of Three Populations of Wild Pear Tree (Pyrus boisseriana). Biotechnology, Agronomy, Society and Environment, 18, 353366.

Zlatev, Z., Lidon, F.C. (2012). An Overview on Drought Induced Changes in Plant Growth, Water Relations and Photosynthesis. Emirates Journal of Food and Agricultural, 24(1), 57-72. doi: 10.9755/ ejfa.v24i1.10599

\section{Aktivnost antioksidativnih enzima u ponicima grahorica u uslovima suše}

\section{Dušica Jovičić · Zorica Nikolić · Aleksandar Mikić · Branko Milošević · Dragana Milošević · Maja Ignjatov · Dragana Marinković}

Sažetak: Suša značajno utiče na normalan rast i razvoj biljaka ugrožavajući fiziološke i biohemijske procese. U nepovoljnim uslovima spoljašnje sredine, antioksidantni sistemi zaštite u biljnim ćelijama mogu se aktivirati bez obzira na fazu rasta i razvoja biljaka. Ovaj eksperiment je sproveden na tri vrste grahorica (V. sativa, V. villosa i $V$. pannonica) u uslovima suše indukovane PEG-om. Aktivnost antioksidantnih enzima superoksid dismutase (SOD), askorbat peroksidaze (APx) i katalaze (CAT) merena je u nadzemnom delu i korenu ponika starim deset dana. Nedovoljna količina vode u početnim fazama rasta aktivirala je sve ispitivane antioksidativne enzime u nadzemnom delu i u korenu ponika svih ispitivanih vrsta roda Vicia. Aktivnost SOD i APx se povećala na višim nivoima stresa, dok su se kod enzima katalaza uočili različiti obrasci delovanja u svim testiranim vrstama. Rezultati ovog eksperimenta ukazuju na povećanu produkciju radikala kiseonika u sušnim uslovima koji dovode do oksidativnog stresa u biljkama.

Ključne reči: antioksidativni enzimi, grahorice, oksidativni stress, suša 